\title{
IDENTIFYING TOURISM MARKET GROWTH OPPORTUNITIES AND RISKS IN THE AUTONOMOUS REPUBLIC IN AJARA (GEORGIA)
}

\author{
Ekaterine Bakhtadze ${ }^{1}$, PHD of Economics, Assoc.Prof.; Nargiz Phalavandishvili², Business \\ Administration Doctor, Assist. Prof.; Natalia Robitashvili ${ }^{3}$, Business Administration Doctor, \\ Assoc. Prof. \\ 1,2,3Batumi Shota Rustaveli State University
}

\begin{abstract}
With the current trends in tourism development and competition in the world, the growth of the tourism market in the Autonomous Republic of Adjara faces certain challenges. Positioning Adjara as a maritime tourist destination is becoming less attractive for tourists. Based on the situational analysis we have identified the existing and new tourism markets and products that in the intermediate-term perspective will enable the growth of tourists and the development of tourism in the region during all four seasons. Based on the expert method and factorial analysis, we assessed the risks of rural and mountain tourism development, which appear to be of the biggest interest of the existing and the new markets. We have ignored the risks that emerge in the macroenvironment and put our focus on the risks that should be overcome by all interested parties, in particular the industry of hospitality and the local government. As the results of the research reveal, rural and mountain tourism development is related to high risk and, according to the risk matrix, the highest risk factors include road and transport infrastructure, tourism and supplementary infrastructure, communal infrastructure and problems associated with the quality of service.
\end{abstract}

Keywords: tourism market, factor analysis, tourism statistics, Ansoff Matrix, risk matrix JEL Code: M31, Z32

\section{Introduction}

Georgia is traditionally a tourist country. Due to natural-recreational resources, cultural attractions, Georgian hospitality, and intangible cultural treasures, it is increasingly becoming an attractive tourist destination for foreign tourists. The growing trend of tourism is confirmed by the increasing flow of visitors and tourists in the country. In 2019, the number of international visits for tourism purposes was 7725 774, which is $7.3 \%$ higher than the previous year (Georgian National Tourism Administration, 2019).

The Adjara region, located in the south-western part of Georgia, on the Black Sea coast, is an autonomous republic. It has an area of $2900 \mathrm{sq}$. km, a population of 334,000 people and two coastal and three mountainous municipalities. There are 6 resorts and 11 recreational areas in Adjara. Adjara holds second place after the capital - Tbilisi, in terms of visits and existing tourism infrastructure. In 2019 , the number of foreign visitors in Adjara exceeded 2.3 million. This number is increased by $8 \%$ since 2017. In 2018, the number of tourists amounted to 862262 persons and among them, foreign tourists accounted for $66 \%$ of the total number of tourists (National Statistics office in Georgia, 2018). Tourism is one of the priority directions of Adjara Autonomous Republic's economy. In 2019, $19 \%$ of total foreign direct investment ( 40 million USD) came from the hospitality industry.

As of 2018, with the number of foreign visitors to Adjara the leading international tourist markets were Turkey (833,486 visitors), Azerbaijan (204,562 visitors), Russia (119,704 visitors), Israel (73,979 visitors) and Ukraine (45,849 visitors). Compared to 2017 , the highest growth rate of visitors is observed in the three countries: Israel - $55.3 \%$, Ukraine - $44.2 \%$ and Russia - $34.1 \%$. At present, the promotional activities of the Department of Tourism and Resorts of the Adjara Autonomous Republic are mainly aimed at exploring new tourism markets such as Poland, the Baltic States, Germany, Great Britain, Saudi Arabia, and the United Arab Emirates.

\footnotetext{
${ }^{1}$ Ekaterine Bakhtadze e-mail: bakhtadze.ekaterine@bsu.edu.ge

${ }^{2}$ Nargiz Phalavandishvili e-mail: phalavandishvili.nargiz@bsu.edu.ge

${ }^{3}$ Natalia Robitashvili e-mail: nato.robitashvili@bsu.edu.ge
} 
The purpose of our research is to study the growth opportunities of the Adjara tourism market based on situational analysis and to identify and evaluate the risks associated with them based on factor analysis. In the setting of enhanced competition and trends in the world tourism market (transition from passive to active leisure, intensification of leisure, ecological care and promotion of healthy lifestyle), it is important to properly assess the current situation and identify those tourism products that, over the medium term, will help expand existing markets and develop new markets (Chaudhary M., 2010).

\section{Research results and discussion}

To analyse the situation in the Adjara tourism market and evaluate the opportunities for market growth, based on the principles of strategic marketing planning, we can use the Ansoff Matrix, which relies on various market growth alternatives (Market penetration, Market extension, Product development, and Diversification). It is the best model for identifying new opportunities for intensive market growth (Kotler Ph., Bowen J., Makens J. C., 2010).

Ansoff's (1956, 1987) Matrix allows us to identify the risks associated with market growth strategies. In addition, developing strategies is based on the information that we receive from the product life cycle and portfolio matrix (McDonald M., 2008).

Based on a situational analysis done by studying such secondary information, such as Adjara Tourism Market Research (2015-2018), Adjara Tourism Brand Strategy (2017), Adjara Tourism Development Strategy (2019-2025) and statistical materials, we tried to identify existing/new products and markets (Tourism and Resorts Department of Adjara Autonomous Republic, 2019). As a result, based on the product lifecycle, we have divided tourism products into two categories:

- Products on the market - developed and developing. Developed products include Maritime Tourism (sun and sea) and Gambling Tourism (casinos) and developing products - Rural, Mountain, Ecotourism, Adventure Tourism, and MICE Tourism. Existing products allow for the penetration of the current market and the development of new markets.

- Sport Tourism and Tourism for the Elderly can be considered as new products on the market. These tourism directions are distinguished by their peculiarity and require the creation of specialized touristic infrastructure. Currently, the Government of Adjara supports the development of both products and facilitates the attraction of investments and the development of so-called PPP projects

Table 1 and Table 2 provide an opportunity to analyse the growth opportunities for current and new markets with existing products. 


\section{Growth opportunities for existing markets with existing products}

\begin{tabular}{|c|c|}
\hline Existing Markets & Existing Products \\
\hline $\begin{array}{l}\text { Domestic tourists traveling throughout their } \\
\text { home country who wants to relax and get } \\
\text { new feelings and excitements. }\end{array}$ & $\begin{array}{l}\text { Maritime tourism (sun and sea), however, this also reveals } \\
\text { competition from Turkey and Egypt. Many Georgian tourists } \\
\text { find the above country resorts to be cost-competitive and } \\
\text { often complain about the quality and price discrepancy in the } \\
\text { market; } \\
\text { Mountain tourism. Actually, this product is just now picking } \\
\text { up the force and is linked to the emerging Goderdzi resort, } \\
\text { where both public and private investments have been made } \\
\text { recently to create appropriate, high standard tourism } \\
\text { infrastructure: ski lifts, cottages, food facilities, and hotels; } \\
\text { Weekend visits often associated with cultural and social } \\
\text { events. }\end{array}$ \\
\hline $\begin{array}{l}\text { New generation tourists from post-Soviet } \\
\text { countries: In post-Soviet countries, the } \\
\text { older generation remembers Adjara very } \\
\text { well and in their minds, it is positioned as a } \\
\text { seaside region, however: it is important to } \\
\text { consider young people who are new market } \\
\text { and offer them an attractive tourist } \\
\text { destination with European elements. Polish } \\
\text { tourists are characterized by similar } \\
\text { consumer behaviour. }\end{array}$ & $\begin{array}{l}\text { Maritime tourism (sun and sea); } \\
\text { Rural Tourism - as a product is in a developing phase. } \\
\text { Families in the village are gradually learning to host visitors, } \\
\text { improve service and infrastructure as the demand increases. } \\
\text { Slavic tourists love to be close to nature and the } \\
\text { communication with Georgian hosts; } \\
\text { Ecotourism; } \\
\text { Mountain Tourism. }\end{array}$ \\
\hline $\begin{array}{l}\text { Tourists from Turkey, Israel, and the Middle } \\
\text { East: Visitors to Batumi at the weekends, } \\
\text { mostly Turkish and Iranian tourists, added } \\
\text { by groups from Israel and families from the } \\
\text { Gulf countries. }\end{array}$ & $\begin{array}{l}\text { Business visits. This is especially true for Turks and Iranians } \\
\text { who do business in Adjara. } \\
\text { Gambling Tourism. The gambling business today has become } \\
\text { a guarantor of the hotel occupancy in the off-season period. } \\
\text { Casinos are in high demand from this market segment } \\
\text { visiting Adjara throughout the year, sometimes in groups, } \\
\text { sometimes individually; } \\
\text { Rural Tourism. Tourist from Israel is interested in rural } \\
\text { tourism. In rural areas, families are focused on hosting their } \\
\text { groups. They offer Georgian dishes to tourists from Israel and } \\
\text { present Georgian folklore. Turks and Iranians are not } \\
\text { interested in such services; } \\
\text { Ecotourism. }\end{array}$ \\
\hline
\end{tabular}

Source: author's created based on Information of Department of Tourism and Resorts of Adjara Autonomous Republic: results of marketing surveys in the years (2015-2018) and Adjara Tourism Brand Strategy (2017)

\section{Growth opportunities for new markets with existing products}

\begin{tabular}{|l|l|}
\hline \multicolumn{1}{|c|}{ New Markets } & Existing Products \\
\hline Tourists from the West: People who have & Rural Tourism; \\
visited European cities many times and want & Adventure Tourism; \\
to discover something new. Currently, the & Ecotourism; \\
main target markets are - Germany, France, & MICE Tourism; \\
Baltic countries, Great Britain. & Mountain Tourism. \\
\hline
\end{tabular}

Source: author's created based on Information of Department of Tourism and Resorts of Adjara Autonomous Republic: results of marketing surveys in the years (2015-2018) and Adjara Tourism Brand Strategy (2017)

In light of the above, currently, we believe that to diversify Adjara's tourism offerings and increase tourism opportunities in the region during all four seasons, governmental and private sector resources should be focused on developing and perfecting such tourism products as Rural Tourism and Mountain Tourism. Therefore, we have sought to identify and assess the risk factors that will become the hindering factors of their development for the following 3-5 years based on a survey of interested parties in the tourism and hospitality sector.

According to the World Tourism Organization definitions, Rural Tourism is "a type of tourism activity in which the visitor's experience is related to a wide range of products generally linked to nature-based activities, agriculture, rural lifestyle/culture, angling, and sightseeing“. Mountain Tourism is a type of "tourism activity which takes place in a defined and limited geographical space 
such as hills or mountains with distinctive characteristics and attributes that are inherent to a specific landscape, topography, climate, biodiversity (flora and fauna) and the local community. It encompasses a broad range of outdoor leisure and sports activities". Rural and Mountain Tourism have a high potential to stimulate local economic growth and social change because of their complementarity with other economic activities, their contribution to GDP and job creation, and their capacity to promote the dispersal of demand in time (fight seasonality) and along with a wider territory. (World tourism Organization, - https://www.unwto.org/rural-mountain-tourism).

Rural and Mountain Tourism are directions that provide the greatest opportunity to attract tourists to Adjara. The number of guesthouses in the villages of Adjara reaches 200. On average, the guesthouse can accommodate 10 guests at a time. According to the information from tourist information centres, in 2019, 238665 guests visited villages in Adjara, compared to the previous year, this figure has increased by $94 \%$. Currently, due to its proximity to Batumi, the highest demand is for the Machakhela Gorge and Keda Municipality villages. Due to the scarcity of tourist services, the desire to stay in rural areas is generally not high. Foreign tourists enjoy nature in the village, taste Georgian wine, local cuisine and communicate with the locals. Consequently, the development of tourism services in rural areas must fall within the standards (Alliances Lesser Caucuses Programme, 2015). The family in the village should know how to arrange the residential area following market requirements (Abesadze T., 2019). The existing value chain that combines the transportation, accommodation, food and the supply of additional services should be evaluated. Additional services may include - Georgian handcrafting, adequate entertainment services for children and culinary master classes in which visitors will play an active role. Being close to nature is important for visitors. A new world known concept of hotel - Eco / Green Hotel can be connected to Rural Tourism. The two main components unite Rural Tourism and Adventure Tourism, being close to nature and understanding local traditions. As a result, developed rural tourism will surely become a stimulator for the development of Adventure Tourism and Ecotourism. The development of Mountain Tourism in all four seasons is linked to the development of the Goderdzi resort, which is supported by both the governmental and business sectors. The Goderdzi Resort is located in the high mountainous Adjara, 2027 meters above the sea level. It is one of the best for those who love skiing in the unmarked snow. At present, the Goderdzi resort operates 1700-2400 meters of ski lifts, accommodation is provided by cottages and construction of 19 hotels is underway.

Risk is an unforeseen situation that causes deviation from expected results (Chaganava P., 2013). Moreover, a risk is essentially a potential future problem (or opportunity). Risks come about when vulnerabilities in our systems, processes, facilities or resources are exploited by threats (Osborne A., 2012). Hazardous situations are grouped according to many characteristics. In general, risks related to tourism development are categorized as following: natural, security, health-related, political, economic, technological factors and socio-demographic factors (Shaw G., Saayman M., Saayman A., 2012). The purpose of our study was to identify the risks that will most likely hinder further development of mountain and rural tourism at the regional level, based on factor analysis and expert evaluations. Both product developments fall under the subject of identical risks.

Qualitative, quantitative and statistical research methods were used in the research. First, we describe (Abesadze N., Qinqladze R., Chitaladze Q., 2018) and group the risks identified during the research process (Table 3). A special questionnaire was developed to enable specialists in the tourism and hospitality industry to rank risks, determine risk severity and the likelihood of risk detection. 
List of major risks and their description

\begin{tabular}{|c|c|c|}
\hline No & Risk Name & Risk Description \\
\hline \multirow{4}{*}{1} & \multirow{4}{*}{ Infrastructure } & $\begin{array}{l}\text { The unregulated road and transport infrastructure, the poor } \\
\text { quality of public transport organization and service; }\end{array}$ \\
\hline & & $\begin{array}{l}\text { Tourist and supplementary infrastructure - insufficient number } \\
\text { of accommodation, food, shopping, medical facilities, etc.; }\end{array}$ \\
\hline & & $\begin{array}{l}\text { Informational-communication infrastructure - Inadequate } \\
\text { access to the Internet, insufficient number of information centres, } \\
\text { signs and boards; }\end{array}$ \\
\hline & & $\begin{array}{l}\text { Communal Infrastructure - water, sewage system malfunction, } \\
\text { gas, and electricity supply problems, waste management problems. }\end{array}$ \\
\hline 2 & Quality of Service & $\begin{array}{l}\text { Low quality of hospitality management - Low-qualified staff, } \\
\text { language barrier, insufficient ability to organize the business. }\end{array}$ \\
\hline 3 & Competition & $\begin{array}{l}\text { Competition from the other regions of Georgia that specialize in } \\
\text { rural and mountain tourism. }\end{array}$ \\
\hline 4 & $\begin{array}{l}\text { Investment } \\
\text { interest }\end{array}$ & $\begin{array}{l}\text { Less attraction from investors for the new tourist destination } \\
\text { (Goderdzi Resort, Gomarduli, and rural settlements). }\end{array}$ \\
\hline 5 & Coordination & $\begin{array}{l}\text { Low level of cooperation and communication between the public and } \\
\text { private sectors, information vacuum. }\end{array}$ \\
\hline 6 & $\begin{array}{l}\text { Recognition and } \\
\text { Branding }\end{array}$ & Insufficient promotional activities. \\
\hline 7 & Natural factors & Natural disasters, climate change, environmental problems. \\
\hline
\end{tabular}

Source: author's created based on results of the survey

With the questionnaire, experts were asked to evaluate the following 10 risk factors: Road and Transport Infrastructure, Communal Infrastructure, Informational-Communication Infrastructure, Tourist and Auxiliary Infrastructure, Quality of Service, Competition, Investment Interest, Coordination, Natural Factor, Recognition and Branding. 96 respondents participated in the study. Including government officials directly involved in defining tourism policy in the region, representatives of non-governmental and consulting organizations supporting tourism development, hospitality industry representatives, academics and tourism agencies/operators representatives.

Through the risk ranking scale, we tried to identify those risk zones (low, high, critical, impermissible) that apply to further development of Mountain and Rural Tourism. Statistical risk assessment can be performed through the expert-point assessment of risk factors.

To assess the severity of the risks associated with rural tourism and mountain tourism development, the risk factors not exceeding 10 are ranked by the level of risk severity (Table 4). Each one is assigned a score of $0-10\left(B_{i}\right)$, the risk severity scale is divided into the following: 1-2 points - the risk is insignificant, 3-4 - the risk is minimal, 5-6 - the risk is medium, 7-8 - the risk is critically important, $9-10$ - the risk is catastrophic. For certain factors, the weight $\left(W_{i}\right)$ was determined through the expert method, reflecting the weight of the influence factor, from the total risk. The sum of weights equals one. The absence of any factors is valued at zero (Beliaevski I. K., 2001), (Gelashvili S.,2017). 
Risk severity assessment of Rural Tourism and Mountain Tourism Development

\begin{tabular}{|l|l|c|c|c|}
\hline No & \multicolumn{1}{|c|}{ Risk Name } & \multicolumn{1}{|c|}{$\begin{array}{c}\text { Risk Severity } \\
\boldsymbol{B}_{\boldsymbol{i}}\end{array}$} & $\begin{array}{c}\text { Weight of risk factors } \\
\boldsymbol{W}_{\boldsymbol{i}}\end{array}$ & $\boldsymbol{B}_{\boldsymbol{i}} \boldsymbol{W}_{\boldsymbol{i}}$ \\
\hline 1 & Road and transport infrastructure & 7 & 0.18 & 1.30 \\
\hline 2 & Tourist and supplementary infrastructure & 7 & 0.13 & 0.82 \\
\hline 3 & Informational-Communication Infrastructure & 5 & 0.09 & 0.48 \\
\hline 4 & Communal infrastructure & 7 & 0.12 & 0.77 \\
\hline 5 & Quality of Service & 7 & 0.13 & 0.88 \\
\hline 6 & Competition & 5 & 0.07 & 0.34 \\
\hline 7 & Investment interest & 5 & 0.08 & 0.40 \\
\hline 8 & Coordination & 5 & 0.07 & 0.38 \\
\hline 9 & Natural & 5 & 0.06 & 0.29 \\
\hline 10 & Recognition and Branding & 5 & 0.08 & 0.40 \\
\hline $\boldsymbol{\Sigma}$ & & & & 6.06 \\
\hline
\end{tabular}

Source: author's calculations based on results of the survey

The average risk is determined by the formula:

$$
R=\sum B_{i} W_{i}=6.06
$$

The risk zone represents the boundaries (Table 5), where the risk does not exceed the specified values.

Table 5

Risk Zone Boundaries

\begin{tabular}{|l|l|}
\hline Risk Zone Boundaries & \multicolumn{1}{c|}{ Risk zones } \\
\hline 0 & No-Risk Zone \\
\hline $0.1-2.5$ & Minimum risk zone \\
\hline $2.5-5.0$ & Elevated risk zone \\
\hline $5.1-7.5$ & Critical Risk Zone \\
\hline $7.6-10.0$ & Impermissible Risk Zone \\
\hline
\end{tabular}

According to the points given by the 96 experts, malfunctioning road and transport infrastructure is the most impeding and critically important risk factor for the development of rural tourism and mountain tourism (average score - 7.13 points), 21 experts gave it 10 points and the risk share amounted to the $18 \%$ of the total volume. Quality of service (6.64 points), Communal infrastructure (6.57 points), Tourist and supplementary infrastructure (6.47 points) were also identified as critically important risks.

In addition, a risk matrix was developed to assess the risk factors affecting the development of rural and mountain tourism, which allows for the determination of the consequence and likelihood of each threat. Experts rated the likelihood of identifying risk factors (problems) with the following points, specifically Unlikely - 1 point, Seldom - 2 points, Occasionally - 3 points, Likely - 4 points, Definitely - 5 points. And the Consequence with the following points: Insignificant - 1 point, Marginal - 2 points, Moderate - 3 points, Critical - 4 points and Catastrophic - 5 points. 


\section{Risk Assessment Matrix for rural and mountain tourism development in Adjara Region}

\begin{tabular}{|c|c|c|c|c|c|c|c|}
\hline \multicolumn{7}{|c|}{ Risk Assessment Matrix } & \\
\hline & & & & ikelihood & & & \\
\hline & & 1 & 2 & 3 & 4 & 5 & Low Risk \\
\hline \multirow{5}{*}{ 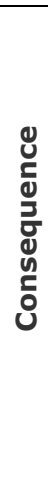 } & 1 & 1 & 2 & 3 & 4 & 5 & Moderate Risk \\
\hline & 2 & 2 & 4 & 6 & 8 & 10 & High Risk \\
\hline & 3 & 3 & Competition, Natural (6) & $\begin{array}{c}\text { Informational- } \\
\text { Communication } \\
\text { infrastructure } \\
(9)\end{array}$ & 12 & 15 & Extreme Risk \\
\hline & 4 & 4 & $\begin{array}{c}\text { Investment Interest, } \\
\text { Coordination, } \\
\text { Recognition and } \\
\text { Branding (8) }\end{array}$ & $\begin{array}{c}\text { Communal } \\
\text { infrastructure; } \\
\text { Tourist and its } \\
\text { supplementary } \\
\text { infrastructure; } \\
\text { Quality of } \\
\text { Service (12) }\end{array}$ & $\begin{array}{l}\text { Road and } \\
\text { Transport } \\
\text { Infrastructure } \\
\text { (16) }\end{array}$ & 20 & \\
\hline & 5 & 5 & 10 & 15 & 20 & 25 & \\
\hline
\end{tabular}

Source: author's created matrix based on results of the survey

Qualitative analysis of risk factors allows us to draw conclusions on the events of high or low negative effects of threats. When applying the risk matrix, the road-transport infrastructure fell in the extreme risk zone, the average value of the points given by the experts in case of risk severity was 3.6 points and in case of risk detection - 3.8 points.

\section{Conclusions, proposals, recommendations}

The risk matrix enables us to better understand, analyse, and draw the following conclusions:

1) Access to tourist destination sites is a critical factor in the development of tourism; consequently, the unregulated transport and road infrastructure have been assessed as an extreme risk. Road infrastructure is mainly important in the case of Goderdzi Resort, and the transport infrastructure is crucial for the rest of the locations - problems with public transport (inconvenient schedules, old vehicles, missing bus stations).

2) Insufficient development of Communal, Tourist and its supplementary infrastructure and low quality of service were assessed as high risk. Standards-based accommodation and supply of other auxiliary services, hygienic-sanitation conditions, and hospitality management knowledge is crucial for the sustainable development of Rural Tourism.

3) Internal competition and risks caused by natural factors were assessed as moderate risk. Coordination between the state and business sectors and the lack of resources appropriated to address the region's awareness were also included in the moderate-risk group.

4) Conducted research and analysis based on risk matrix confirmed that Rural Tourism and Mountain Tourism in Adjara are developing products and as a result are associated with high risks. Therefore, for the further growth of the Adjara tourism market, it is very important to deal with extreme and high-risk problems that will become a significant barrier to their development in the medium term, on time.

\section{Bibliography}

1. Abesadze, T. 'Management and Organization of Tourism Business in private houses in villages '(2019) Batumi pp. 102-109.

2. Abesadze, N., Qinqladze, R., Chitaladze, Q. Statistics for Tourism (2018)., Tbilisi: Manual pp. 317-330.

3. Alliances Lesser Caucasus Programme, Rural Tourism Market Analysis (2015)., pp. 6-10.

4. Aziri, B., Nedelea, A., Business strategies in Tourism, (2013). ECOFORUM ,Volume 2, Issue 1(2), 2013 p. 6.

5. Beliaevski, I. K., Marketing Research: Information, Analyse, Forecasting (2001)., Moscow: Finance and Statistics, pp 274-275.

6. Chaudhary, M., Tourism Marketing. (2010)., Oxford University Press, pp 102-103. 
7. Chaganava, P. Risk Management. (2013)., Tbilisi, pp 70-72.

8. Gabidzshvili, B., Statistics in Economics, Business and Management, (2011)., Tbilisi, pp. 656-663.

9. Gelashvili. S., Statistic Forecasting in Economics and Business, (2017)., Tbilisi, pp. 237-251

10. Georgian National Tourism Administration. Retrieved: https://gnta.ge/statistics/ Access: 30.03.2020.

11. Kotler, P.H., Bowen J. T., Makens James C. Marketing for Hospitality and Tourism. (2010). Boston: Person pp. 64-65.

12. McDonlad M., Malcolm McDonald on Marketing Planning: Understanding Marketing Plans and Strategy. (2008). London and Philadelphia: Kogan Page, pp 82-83.

13. Osborne, A. Risk Management Made Easy (2012). pp. 30-32.

14. Robitashvili, N., Tourism Statistics in Georgia, (2018). International Journal of Innovative Technologies in Economy, 6(18), Vol. 2, July 2018.

15. National Statistics office in Georgia. Retrieved: https://www.geostat.ge/regions/\# Access: 30.03.2020.

16. Shaw. G., Saayman, M., Saayman, A., Identifying Risks Facing the South African Tourism Industry (2012). SAJEMS NS 15 . No 2193 p. 193

17. Statistics for Economics and Business. Lecture course. Ivane Javakhishvili Tbilisi State University., (2017). Faculty of economics and social statistics, Tbilisi, pp. 54-57

18. Tourism and Resorts Department of Adjara Autonomous Republic, Market research reports (2015-2017). Retrieved: http://adjara.gov.ge/branches/listpage.aspx?pid=1352\&gid=7\&ppid=334 Access: 30.03.2020.

19. Tourism and Resorts Department of Adjara Autonomous Republic, Adjara Tourism Brand Strategy (2017). pp 3-10.

20. Tourism and Resorts Department of Adjara Autonomous Republic, Adjara Tourism Development Strategy (2019-2025) pp 3-4.

21. World tourism Organization. Retrieved: https://www.unwto.org/rural-mountain-tourism Access: 30.03.2020. 